\title{
Factors Impacting Workers' Decision to Accommodation Types in Ho Chi Minh City
}

\author{
Phuong-Thao Hoang-Thi', Shiann-Far Kung ${ }^{2}$, Hsueh-Sheng Chang ${ }^{2}$ \\ 1PhD Student, 2 Professor, Department of Urban Planning, \\ National Cheng Kung University, Taiwan
}

P28077016@gs.ncku.edu.tw, sfkung@mail.ncku.edu.tw, changhs@mail.ncku.edu.tw Tel: +886-908-099-514

\begin{abstract}
In any industrial planning project in Vietnam, housing for workers is always a top concern. However, these planned accommodations have not met workers' needs; Instead, they usually opted for housing out of planning. By carrying out a field survey, using exploratory factor analysis (EFA) and multiple regression methods, this research will discover new factors and examine the relationships among variables to determine the elements that influence the workers' choice in $\mathrm{Ho}$ Chi Minh City (HCMC). It may lead to the planning re-evaluation and adjustments to meet the demands of workers.
\end{abstract}

Keywords: Workers' decision; Accommodation types; Exploratory factor analysis (EFA); Multiple regression analysis.

eISSN: 2398-4287@ 2020. The Authors. Published for AMER ABRA cE-Bs by e-International Publishing House, Ltd., UK. This is an open access article under the CC BYNC-ND license (http://creativecommons.org/licenses/by-nc-nd/4.0/). Peer-review under responsibility of AMER (Association of Malaysian Environment-Behaviour Researchers), ABRA (Association of Behavioural Researchers on Asians) and cE-Bs (Centre for Environment-Behaviour Studies), Faculty of Architecture, Planning \& Surveying, Universiti Teknologi MARA, Malaysia. DOI: https://doi.org/10.21834/ebpj.v5i15.2460.

\subsection{Introduction}

Industrial zones are planned as the economic dynamics of an area or a city. In implementing an industrial planning project, workers' housing is always a top concern (Noltze, 2008). By 2020, Ho Chi Minh City has three export processing zones (EPZs), and sixteen industrial zones (IZs) established with a total area of 4,532 ha (HEPZA, 2020). There will be around 400,000 workers with 280,000 accommodation needs. Ho Chi Minh City faces a housing shortage (La, Tran, \& Nguyen, 2019). To solve that problem, the government develops affordable housing types for workers, including dormitories, social housing, and cheap apartment (Agency, 2018; Minister, 2017). However, these housing types still faced supply shortages, slow construction progress, low quality, and price speculation (Agency, 2018). The biggest issue is these projects do not meet the worker's needs (L. M. Ngo, Le, Hoang Thi, Nguyen, \& Lam, 2017). This problem has led to new unregulated residential areas or increased residential density in existing neighborhoods. These inadequacies directly affect the quality of life (L. M. Ngo et al., 2017). Thus, it is critical to identify and examines the factors that influence workers' accommodation choices in Ho Chi Minh City.

\subsection{Literature review}

While developed countries (Europe, America, Singapore, Japan, etc.) gradually shift their economic structure from industry to services, developing countries (China, India, Vietnam, etc.) quickly became the factory of the world with abundant human resources and cheap labor (CNUCED, 2018).

Housing for workers becomes an urgent task. Studies on worker housing modalities are conducted on a variety of aspects such as

eISSN: 2398-4287C 2020. The Authors. Published for AMER ABRA cE-Bs by e-International Publishing House, Ltd., UK. This is an open access article under the CC BYNC-ND license (http://creativecommons.org/licenses/by-nc-nd/4.0/). Peer-review under responsibility of AMER (Association of Malaysian Environment-Behaviour Researchers), ABRA (Association of Behavioural Researchers on Asians) and cE-Bs (Centre for Environment-Behaviour Studies), Faculty of Architecture, Planning \& Surveying, Universiti Teknologi MARA, Malaysia.

DOI: https://doi.org/10.21834/ebpj.v5i15.2460. 
build some housing models for workers (cheap rental housing - $\mathrm{CRH}$, minimum living standard assistance - MLSA, public rental housing - PRH); and policies to encourage the development of affordable housing for workers (Morrison, 2014). The factors affecting the housing model and factors influencing the growth of suitable housing types for workers are also involved. Some of the impact factors have been identified through previous studies such as: household characteristics, mobility characteristics, income, education, trade (Tao, Hui, Wong, \& Chen, 2015), the jobs-housing relationship, job opportunities, and housing access (Acolin \& Wachter, 2017; Li \& Liu, 2016).

In Vietnam, with different socio-economic and cultural conditions, studies on housing development policies, housing models suitable for workers, and influencing factors are also performed (L. Ngo, 2018; Rockwood \& Tran, 2016). In 2016, Dao Nhat Tan used EFA to learn about social housing determinants for workers and low-income people. He tried to identify factors that include financial, location, subjective norm, living space, and the environment. Therein, the elements of location, subjective norm, and living space influence social housing reference (Tan, 2016). Until 2018, the social housing and worker dormitories still have many problems that cannot correctly meet workers' needs. Most workers have to rent a room or house with poor living conditions. In addition to the issue of quantity, social housings and workers dormitories are not suitable for workers' living habits, leading to this situation (L. M. Ngo et al., 2017).

Previous studies have not shown all the factors influencing people's decisions or stop at suggesting suitable models of houses. Another limitation is that the impact factors might have been determined subjectively from the researchers' perspective without the methods of specifying those factors. This paper aims to shed more light on the factors influencing workers' decisions in choosing suitable accommodation from a worker's perspective. It is essential to make clear the influential factors to workers' decisions in choosing accommodation types. With the tendency to permanently settle in HCMC of migrant workers (Siu \& Unger, 2020), the study is needed to inform future residential planning development. It will help residential planning projects reasonably meet workers' needs and daily habits in industrial zones.

\subsection{Methodology}

The research group identified the factors by literature review and in-depth interviews with local workers in HCMC. This step helps identify the factors affecting the workers' decisions consistent with previous research and discover new factors specific to HCMC.

Collected data were analyzed through three methods: reliability assessment, exploratory factors analysis (EFA), and multiple linear regression (Aiken, West, Pitts, Baraldi, \& Wurpts, 2012; Fabrigar \& Wegener, 2011). The reliability assessment method helps determine the reliability of a data set. Next, EFA helps understand the relationships of the variables to visualize the factors' influence on the workers' decisions. Finally, the multiple linear regression is used to model linear relationships between explanatory variables (independent) and reactive (dependent) variables. Since then, the results showed the impact level of the identified factors (independent variables) on the worker's decisions on the accommodation types (the dependent variable).

The above methods are closely coordinated to clarify the objectives of the research topic.

\subsection{Study area}

Ho Chi Minh City has been the economic center in Vietnam for a long time and the first city to develop export processing zones and industrial parks. Industrial parks are evenly distributed in the suburbs of Ho Chi Minh City, as shown in figure 1 (HEPZA, 2020). The study was conducted with employees who work in industrial zones in Ho Chi Minh city.

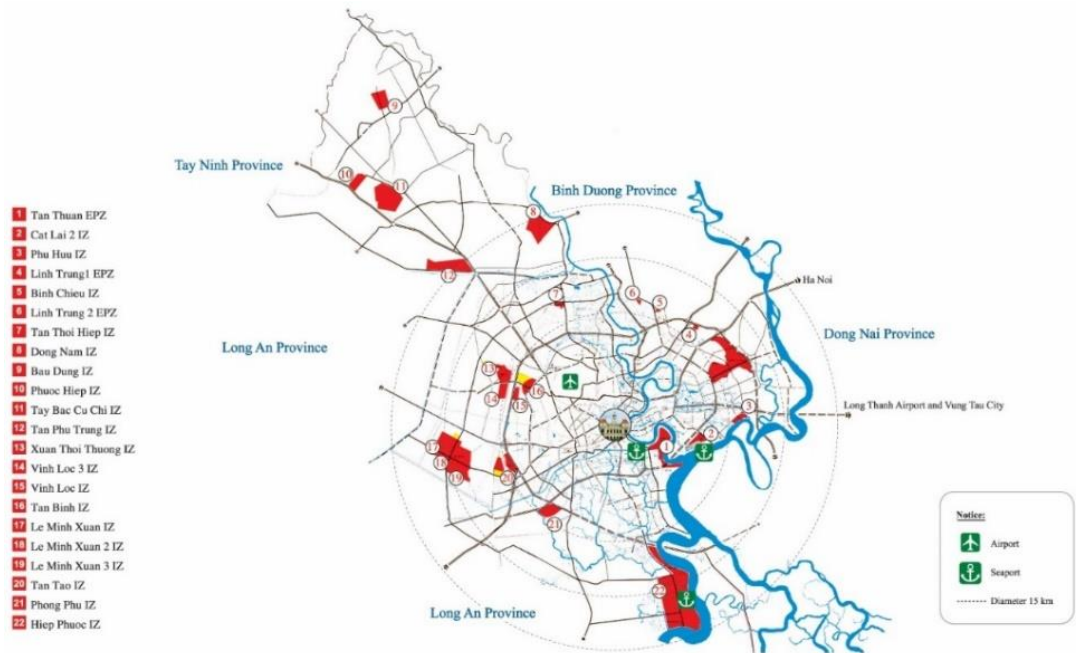

Figure 1. Industrial park location in Ho Chi Minh city by the year 2020. (Source: HEPZA, 2020)

\subsection{Data collection}

The in-depth interviews were conducted with workers in three major industrial zones of HCMC, including Tan Thuan Export Processing Zone, Export Processing Zone Linh Trung, and Hiep Phuoc Industrial Park. The above industrial parks are all multi-industry industrial zones where workers come from many localities across the country. Therefore, this group of workers has a diverse culture, social norms, and lifestyle. They are highly representative, suitable for finding new factors. 
For a population of 400,000 workers, the research needs at least 202 respondents. The number of samples collected was 210 (Comrey \& Lee, 2013; Slovin, 1960; Tabachnick, Fidell, \& Ullman, 2007). The number of testing samples is 25. The random method was applied to collect the samples.

\subsection{Measurement of variables}

The dependent variable is accommodation types include worker dormitories, social housing, and apartment. They are measured by the 5-point Likert scale that changes from 1- "completely not suitable"; 2- "less suitable"; 3- "normal"; 4- "quite suitable"; and 5- "completely suitable".

The study provides questions about family characteristics, ambient characteristics, and neighborhood facilities to measure the independent variables (the factors that influence worker's decisions). These factors are measured on a 5-point Likert scale that changes from 1- "unnecessary", 2- "less necessary"; 3- "normal"; 4- "quite necessary"; and 5- "absolutely necessary".

\subsection{Findings and Discussions}

\subsection{Personal information of respondents}

Personal data of respondents is shown in table 1. The interviews have a relatively balanced gender ratio. The surveyed result shows that the working-age (from 25-50 ages) is the most crowded in industrial zones (65.24\%). Most workers have relatively high education levels (college and bachelor's degrees). The income is relatively high compared to Vietnamese people's average income (from 10-20 million VND / month). However, they usually live with and take care of other family members (from 2-4 people per family), so the savings money to upgrading the quality of life will not be much.

\begin{tabular}{|c|c|c|c|c|c|}
\hline Characteristics & $\begin{array}{l}\text { Number } \\
\text { responders }\end{array}$ & $\begin{array}{l}\text { of } \\
\quad \text { Percentage }(\%) \\
\end{array}$ & Characteristics & $\begin{array}{l}\text { Number } \\
\text { responders }\end{array}$ & of $\quad$ Percentage $(\%)$ \\
\hline Gender & & & Working position & & \\
\hline Male & 98 & 46.67 & Factory workers & 112 & 53.33 \\
\hline Female & 112 & 53.33 & Staffs & 64 & 30.48 \\
\hline Age & & & Managers & 25 & 11.90 \\
\hline $18-24$ & 35 & 16.67 & Senior specialist & 9 & 4.29 \\
\hline & & 4857 & Average income per & & \\
\hline $\begin{array}{l}25-34 \\
35-50\end{array}$ & $\begin{array}{l}102 \\
57\end{array}$ & $\begin{array}{l}48.51 \\
27.14\end{array}$ & $<5$ million VND & 19 & 9.05 \\
\hline upper 51 & 16 & 7.62 & 5-10 million VND & 99 & 47.14 \\
\hline Education level & & & 10-20 million VND & 69 & 32.86 \\
\hline Junior high school & 11 & 5.24 & $>20$ million VND & 23 & 10.95 \\
\hline & & & $\begin{array}{l}\text { Number of family } \\
\text { members currently living } \\
\text { with }\end{array}$ & & \\
\hline Senior high school & 39 & 18.57 & (including you) & & \\
\hline College & 41 & 19.52 & 1 person & 34 & 16.19 \\
\hline Bachelor's degree & 101 & 48.10 & 2-4 person & 117 & 55.71 \\
\hline Master's degree or higher & 18 & 8.57 & $>4$ person & 4 & 1.90 \\
\hline Marital status & & & Total & 210 & 100 \\
\hline
\end{tabular}

The personal information of responders shows the distribution rate of workers' groups and their current status. These informations supports the evaluation process, conclusions as well as development orientation for future planning.

\subsection{Reliability assessment}

After the process of understanding and synthesizing factors from previous researches and local factors (in-depth interviews with workers in HCMC), the independent and dependent variables are listed, as shown in Table 2.

Table 2: Reliability assessments of the factors

\begin{tabular}{|c|c|c|c|}
\hline Type of variable & Variables & Items & Cronbach's alpha \\
\hline Dependent variable & Accommodation types (AT) & $\begin{array}{l}\text { Worker dormitory (AT1) } \\
\text { Social housing (AT2) } \\
\text { Apartment (AT3) }\end{array}$ & 0.658 \\
\hline \multirow[t]{2}{*}{$\begin{array}{l}\text { Independent } \\
\text { variables }\end{array}$} & Family characteristics (FC) & $\begin{array}{l}\text { Income (FC1) } \\
\text { Number of members living with (FC2) } \\
\text { Job opportunities (FC3) }\end{array}$ & 0.604 \\
\hline & Ambient characteristics (AC) & $\begin{array}{l}\text { Near parks and public exercise facilities (AC1) } \\
\text { Near kindergarten and schools (AC2) } \\
\text { Near hospitals/clinics (AC3) } \\
\text { Near market/convenient store (AC4) } \\
\text { Near entertainment center (AC5) } \\
\text { Near public transportation (AC6) }\end{array}$ & 0.793 \\
\hline
\end{tabular}




$\begin{array}{ll}\text { Neighborhood facilities (NF) } & \text { Distance from house to work (AC7) } \\ & \text { Near local police/security stations (NF1) } \\ & \text { The house has a safety fence (NF2) } \\ & \text { Street light (NF3) } \\ \text { CCTV (NF4) } \\ \text { Residential Discipline (NF5) } \\ \text { Sanitation service (NF6) }\end{array}$

The data were cleaned after collection (Sehgal \& Bhargava, 2018) and underwent reliability assessments by SPSS. Variable groups were evaluated with Cronbach's Alpha (Hair, Anderson, Babin, \& Black, 2010). All variables are between 0.658 and 0.793 , upper than 0.06 (DeVellis, 2016; Hair et al., 2010). The Cronbach's Alpha indicators support the data set's sufficient reliability.

\subsection{Factors analysis}

Exploratory factor analysis (EFA) for the group of the independent variable includes Family characteristics ( $F C)$, Ambient characteristics $(A C)$, and Neighborhood facilities (NF). There is no new factor separation with the variable group of FC and NF. However, the group of AC (7 variables) was separated into two new factors. (See table 3). The group of factor 1 included AC5, AC6, and AC1, which was named "entertainment and public transportation (EPT); Factor 2 included AC2, AC3, and AC4, which was named "Education, health and food" (EHF). The AC7 variable of "distance from work to home" was eliminated because its factor loading is smaller than 0.5 .

Table 3: Factor analysis of elements impact to workers' decisions

\begin{tabular}{llcc}
\multicolumn{3}{c}{ Table 3: Factor analysis of elements impact to workers' decisions } \\
\hline Code & Items & Factor 1 & Factor 2 \\
\cline { 3 - 4 } & & $\begin{array}{c}\text { Entertainment and public } \\
\text { transportation (EPT) }\end{array}$ & $\begin{array}{c}\text { Education, health and } \\
\text { food (EHF) }\end{array}$ \\
\hline AC5 & Near entertainment center & 0.863 & \\
AC6 & Near public transportation & 0.826 & \\
AC1 & Near parks and public exercise facilities & 0.619 & \\
AC2 & Near kindergarten and schools & & 0.835 \\
AC3 $\quad$ Near hospitals/clinics & & 0.759 \\
AC4 $\quad$ Near market/convenience store & 3 & 0.653 \\
Number of items & 0.723 & 3 \\
KMO and Barlett's Test, Sig. & Principal Components & 0.000 \\
Extraction, Rotation & 2.770 & Varimax \\
Eigenvalue & 0.713 & 1.009 \\
Cronbach's Alpha & 32.545 & 0.676 \\
Explained Variation (\%) & 32.545 & 30.450 \\
Total Explained Variation (\%) & & 62.995 \\
\hline
\end{tabular}

The initial groups of independent variables are grouped according to the characteristics of each variable. Analysis results show that most of the variables are grouped appropriately and have a certain degree of influence on workers' decisions. Notably, the group 'Ambient characteristics - AC' showed a clear division. The variable AC7 - 'distance from work to home' in this survey showed that it did not influence workers' decisions. This result can be seen as a new finding because, in previous studies, the distance factor showed an apparent influence.

\subsection{Multiple linear regression}

Finally, the relationship of each independent variable (AT1, AT2, AT3) with newly defined factors (FC, EPT, EHF, NF) was evaluated.

\subsubsection{The impact of the factors on workers' decision in choosing the type of "Dormitory" (AT1)}

The relationship between selecting the dormitory of workers (AT1) and all impact factors was evaluated. The results are shown in Table 4. The results of regression analysis show the relationship between the decisions on dormitory selection (AT1) with family characteristics (FC) and neighborhood facilities (NF). The results show that the FC has the most significant impact with AT1 (Standardized coefficients Beta $=0.241$ ) followed by NF (Standardized coefficients Beta $=0.206$ ). Both of these elements reach medium effect sizes.

Table 4: The impact of the factors on worker' decision in choosing the type of "Dormitory" (AT1)

\begin{tabular}{|c|c|c|c|c|}
\hline Dependent variable & Independent variable & $\begin{array}{l}\text { Standardized } \\
\text { coefficients Beta }\end{array}$ & t-Value & Sig. \\
\hline \multirow{3}{*}{$\begin{array}{l}\text { Worker } \\
\text { (AT1) }\end{array}$} & Family characteristics (FC) & 0.241 & 3.410 & 0.001 \\
\hline & Neighborhood facilities (NF) & 0.206 & 2.917 & 0.004 \\
\hline & Adjusted $R$ square $=0.133$ & & $p$-value $=$ & \\
\hline
\end{tabular}

Employees who choose to live in workers' dormitory are strongly influenced by family characteristics (FC) and neighborhood facilities (NF). For the option of "Dormitory," workers often ignore health education elements and often do not cook for themselves. Their income is relatively low, and they choose to live in dormitories for a better quality of life at low prices. This accommodation type can be suitable for single workers, young workers, and much time on work. Meanwhile, the conditions of necessary equipment for daily life and safety and living environment sanitation are still meet the needs. 
4.4.2 The impact of the factors on worker' decision to choose "Social housing" (AT2)

Similarly, the determinants of Social housing (AT2) are shown in table 5. In the selected AT2, only the factor EHF has a relatively strong correlation (Standardized coefficients Beta $=0.381$ ).

Table 5: The impact of the factors on worker' decision in choosing the type of "Social housing" (AT2)

\begin{tabular}{lllll}
\hline Dependent variable & Independent variable & $\begin{array}{l}\text { Standardized } \\
\text { coefficients Beta }\end{array}$ & t-Value & Sig. \\
& & & 5.951 & 0.000 \\
\hline Social housing (AT2) & Education, health and food (EHF) & 0.381 & $\mathrm{p}$-value $=0.000$ & \\
\hline & Adjusted R square $=0.141$ & &
\end{tabular}

The workers who choose to live in social housing are usually the married workers. They have many income sources (income of all family members), so they often pay attention to the primary living standards (healthcare center, market, schools for their children, etc.) to meet the family's needs with reasonable house prices.

4.4.3 The impact of the factors on worker' decision in choosing the type of "Apartment" (AT3)

The dependent variable AT3 is affected by two groups of impact factors, NF and EHF. In which NF had the most substantial impact (Standardized coefficients Beta $=0.257$ ) followed by EHF (Standardized coefficients Beta $=0.257$ ). According to the research results, the subjects choosing "Apartment" are most concerned with the quality of service, safety, and sanitary conditions of the surrounding environment.

Table 6: The impact of the factors on worker' decision in choosing the type of "Apartment" (AT3)

\begin{tabular}{lllll}
\hline Dependent variable & Independent variable & $\begin{array}{l}\text { Standardized } \\
\text { coefficients Beta }\end{array}$ & t-Value & Sig. \\
\hline Apartment (AT3) & Neighborhood facilities (NF) & 0.257 & 3.419 & 0.001 \\
& Education, health and food (EHF) & 0.218 & 2.901 & 0.004 \\
\hline & Adjusted R square $=0.166$ & & p-value $=0.004$ & \\
\hline
\end{tabular}

Next is the basic daily needs (education, health care, and shopping needs for daily activities). It indicates that this target group has a higher demand for quality of life for themselves and their families.

4.4.4 Consider aggregating the effects of factors on workers' decisions In four groups of impact factors influencing workers' decisions to choose housing, it can be seen that the EPT has not shown any impact on home choice decisions.

Table 7: The summary of the impact factors to accommodation types

\begin{tabular}{|c|c|c|c|}
\hline & Dormitory (AT1) & Social housing (AT2) & Apartment (AT3) \\
\hline Family characteristics (FC) & $0.241^{* * *}$ & - & 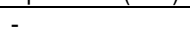 \\
\hline Entertainment and public transportation (EPT) & - & - & - \\
\hline Education, health and food (EHF) & - & $0.381^{* * *}$ & $0.218^{* *}$ \\
\hline \multirow[t]{3}{*}{ neighborhood facilities (NF) } & $0.206^{\star *}$ & - & $0.257^{* \star *}$ \\
\hline & $\mathrm{R} 2=0.133$ & $\mathrm{R} 2=0.141$ & $\mathrm{R} 2=0.166$ \\
\hline & Sig. $=0.004$ & Sig. $=0.000$ & Sig. $=0.004$ \\
\hline
\end{tabular}

The analysis shows that distance to work, public transport stations, and entertainment services are not crucial to the workers. Part of the reason is working hours, overtime work, the widespread use of personal vehicles (motorbikes), the public transport systems, and transportation infrastructure development in $\mathrm{HCMC}$ in recent years. The survey results show that workers still have entertainment needs but are not limited by distance issues.

\subsection{Conclusion \& Recommendations}

According to this study, each type of housing is suitable for different groups of workers. Worker's dormitory is ideal for single workers who tend to move after marriage. Social housing and apartments are ideal for families with higher requirements for the surrounding environment, especially education, health care, and shopping need to serve daily life. However, the group of workers who choose an apartment often has a higher quality of life. They have additional requirements for the neighborhood facilities and security of the area. Thereby, several recommendations can be made.

Firstly, adjusting residential planning to suit the requirement of workers in each locality is needed. Secondly, the worker dormitory only meets the needs of single workers (low rate). The supply should be according to the ratio of real needs of single workers instead of accounting for all workers' demands in HCMC. Thirdly, social housing is a suitable model for most workers. There should be reasonable policies to develop social housing according to the requirements and conditions of workers, solving negative issues to quickly solve the current housing shortage for the low-income group in general and workers in particular in the HCMC. Finally, the social environment factors have a strong impact on the worker's decisions and housing development projects' success. They should be given more weight in a development project in addition to indoor structure designs. 


\subsection{Limitation of study}

The data collection was carried out during the Covid-19 social distance period in Vietnam. The questionnaire was sent to workers via social network sharing. Therefore, the control of accessibility and allocation faces many obstacles. It leads to a possibly weaker data set that does not adequately reflect the realities of workers' preferences.

\section{Acknowledgments}

We want to thank Dr Ngo Le Minh, dean of the architecture department, Ton Duc Thang University, Vietnam, who shared useful information related to the topic. Sincere thanks to the responders who enthusiastically participated in answering the questionnaire to improve the data set to implement this topic.

\section{Paper contribution to the related field of study}

The study specifies more clearly the characteristics of each accommodation type and their impact factors. So, the government has the suitable plans for housing development following local characteristics in the future.

Besides, the importance of housing/accommodation supply in industrial estate development, which has been largely neglected or mistakenly addressed in the previous projects also highlighted through this study.

Moreover, research results show that it is essential to consider people's social needs. Therefore, the improvement of the residential planning process with in-depth assessment and calculations is needed. The completion of the planning process will limit undesirable shortcomings in the implementation of future projects.

\section{References}

Acolin, A., \& Wachter, S. (2017). Opportunity and housing access. Cityscape, 19(1), 135-150.

Agency, V. N. (2018). TPHCM xây 50.000 nhà ở xã hội, chỗ lưu trú cho công nhân. Retrieved from http://tphcm.chinhphu.vn/tphcm-xay-50-000-nha-0-xa-hoi-cho-luutru-cho-cong-nhan

Aiken, L. S., West, S. G., Pitts, S. C., Baraldi, A. N., \& Wurpts, I. C. (2012). Multiple linear regression. Handbook of Psychology, Second Edition, 2.

CNUCED. (2018). World investment report 2018: Investment and new industrial policies: UN.

Comrey, A. L., \& Lee, H. B. (2013). A first course in factor analysis: Psychology press.

DeVellis, R. F. (2016). Scale development: Theory and applications (Vol. 26): Sage publications.

Fabrigar, L. R., \& Wegener, D. T. (2011). Exploratory factor analysis: Oxford University Press.

Hair, J. F., Anderson, R. E., Babin, B. J., \& Black, W. C. (2010). Multivariate data analysis: A global perspective (Vol. 7). In: Upper Saddle River, NJ: Pearson.

HEPZA, H. C. M. C. E. P. Z. A. (2020). Table of land lease price for reference in HCMC's export processing \& industrial zones. Retrieved from http://www.hepza.hochiminhcity.gov.vn/web/hepza-eng/kcn_kcx-tphcm/bang-gia-dat

La, H. A., Tran, T. B., \& Nguyen, U. (2019). Housing Gaps Between Rural-Urban Migrants and Local Urban Residents: The Case of Vietnam. In Rural-Urban Migration in Vietnam (pp. 211-243): Springer.

Li, S.-m., \& Liu, Y. (2016). The jobs-housing relationship and commuting in Guangzhou, China: Hukou and dual structure. Journal of Transport Geography, 54, $286-294$.

Minister, T. P. (2017). Directive No. 03 / CT - TTg dated January 25, 2017. Vietnam Government Portal: Vietnam Government Office

Morrison, N. (2014). Building talented worker housing in Shenzhen, China, to sustain place competitiveness. Urban Studies, 51(8), 1539-1558.

Ngo, L. (2018). Social housing for workers-A new housing model for Ho Chi Minh City, Vietnam. E\&ES, 143(1), 012060.

Ngo, L. M., Le, T. H., Hoang Thi, P. T., Nguyen, D. N., \& Lam, Q. T. (2017). Spatial Organization of Social Housing in Ho Chi Minh City: Building a model in view of the users. Ho Chi Minh City: Ho Chi Minh City Department of Science and Technology

Noltze, M. (2008). Backyard Living-Intergrative Policies Towards Migrant Workers: Housing Microfinance in Greater Ho Chi Minh City, Vietnam. Austrian Journal of SouthEast Asian Studies, 1(2), 19-33.

Rockwood, D., \& Tran, D. Q. (2016). Urban immigrant worker housing research and design for Da Nang, Viet Nam. Sustainable Cities and Society, 26, 108-118.

Sehgal, M., \& Bhargava, D. (2018). Knowledge mining: An approach using comparison of data cleansing tools. Journal of Information and Optimization Sciences, 39(1), 337-343.

Siu, K., \& Unger, J. (2020). Work and Family Life among Migrant Factory Workers in China and Vietnam. Journal of Contemporary Asia, 50(3), 341-360.

Slovin, E. (1960). Slovin's formula for sampling technique. Retrieved on February, 13, 2013.

Tabachnick, B. G., Fidell, L. S., \& Ullman, J. B. (2007). Using multivariate statistics (Vol. 5): Pearson Boston, MA.

Tan, D. N. (2016). Factors affecting the preferences of social housing: Evidence from Ho Chi Minh city.

Tao, L., Hui, E. C., Wong, F. K., \& Chen, T. (2015). Housing choices of migrant workers in China: Beyond the Hukou perspective. Habitat International, 49, 474-483. 